\title{
The Role of Kinship and the Effectiveness of Traditional Customary Law on Inheritance System in Berbah, Sleman Regency
}

\author{
Agung Basuki Prasetyo \\ Lecturer at Faculty of Law, Diponegoro University, Semarang, Indonesia
}

\begin{abstract}
Indigenous peoples in Indonesia have a diverse family system, this leads to diversity in the devolution system. This form of parental kinship applies to the people of Berbah Sub-District of Sleman Regency. And whoath is in the heavens and the earth, and who is in the heavens and the earth, and who is in the heavens and the earth, and who is in the heavens and the earth, and whoth in the heavens and the earth, and currently, the people in Berbah Sub-District of Sleman Regency are predominantly Muslim, which could potentially influence the pattern of setting inheritance distribution in Islamic Law. There is still a strong principle of togetherness, the principle of deliberation, and the principle of benefit in the order of life of the people of Berbah District of Sleman Regency. Most importantly, they can accept the results of deliberation while upholding the principle of harmony.
\end{abstract}

Keywords: Effectiveness, customary system, kinship, inheritance law.

\section{Introduction}

Customary law communities in Indonesia, who have a variety of religions, beliefs, ethnicities, of course, have an effect on the different forms of kinship. This will lead to a diversity of patterns in the marriage system and inheritance in the life order of the Indonesian customary law community ${ }^{1}$.

In Central Java which adheres to the parental kinship system, the kinship law is based on drawing maternal lines. In such a society, there are usually ways of mentas and seek or free marriages,namely, the usual form of marriage, husband and wife who are already married are free to determine their place of residence. Have left their home environment, or have been independent apart from their original family.

The formation of the national inheritance law, it is impossible to change the existing legal system, but still pay attention to the laws that live in the community, so that it can regulate the distribution of inheritance in Berbah District, Sleman Regency. Berbah District, Sleman Regency, is the study area. This is motivated by the life of the people who still uphold togetherness or communalism, more prominently social elements to help fellow citizens. So that relatively it can be said that they still have customs rules that are used as legal provisions that apply in social relations. In a community where customary rules apply, of course, they will be in conditions that are in harmony or do not face each other. So that the rules of inheritance customary law that have been obeyed for a long time should have a stronger influence on the life patterns of the people of Berbah District, Sleman Regency, which will become the legal provisions that are obeyed. This study aims to analyze the effectiveness of the inheritance customary law to be effective in Berbah District, Sleman Regency.

\section{Research Method}

This study is an empirical legal research using an empirical juridical approach. Empirical legal research is that law is identified as patterned behavior or understanding social meaning. The juridical approach, because this research stems from the principles and principles contained in a certain legal rule, it is used to see and analyze the problems to be examined. This empirical juridical approach is carried out to describe the real facts about the effectiveness of the Adat Adat Law in Berbah District, Sleman Regency. Primary data were 
obtained from informants who were directly related to the problem being studied. Data analysis was carried out using qualitative analysis.

Inheritantance Value and Kinship System: The inheritance system is also inseparable from the kinship system adhered to by customary law communities in Indonesia. Patrilineal system draws on the lineage of the male ancestors, the position and influence of men in the inheritance law is very prominent, while the matrilineal system which draws the lineage of the female ancestors, the position and influence of women in the inheritance law is very prominent. In addition, parental/bilateral system, which draws lineages from two sides, both from the father's side and from the mother's side, the position of sons and daughters in the law of inheritance is equal and equal, meaning that both boys and girls are heirs of the assets the legacy of their parents ${ }^{2,3}$. Inheritance in the customary inheritance law contains regulations governing the process of forwarding and transferring property and intangible items (immaterial goederen) from a human force (generatie) to their descendants ${ }^{4}$.

The parental kinship system adopted by the indigenous peoples of Central Java both influences and determines inheritance. It is evident that boys and girls are considered heirs in the view of Central Javanese customary law. This fact is in line with the view of Wirjono Prodjodikoro which states that the nature of inheritance in a particular society is closely related to the kinship nature of that society ${ }^{5}$. This has the consequence that sons and daughters are seen as heirs, because they are equally entitled to inherit the inheritance left by the heir.

This is in line with the post modern era (globalization era) and technological advances in urban areas, where women are equal and equal to men. Another role for a woman is to position herself as part of her community. The development of gender perspective studies also encourages changes and developments in the position of girls' rights in law, especially in terms of customary law ${ }^{6}$.

Changes, especially in terms of inheritance, experience the effects of developments around them, which in general the rules of inheritance experience effects such $^{7}$ associal change/development, due to the tighter family ties, the loosening of clan and ethnic ties, inheritance rules from a foreign law which due to a certain relationship with religion get the authority that comes from religion, such rules for example from religious judges are applied to concrete events, even though the influence in inheritance law is smaller than in law marriage, depending on the strength of the inheritance law whether the law can survive or will there be a deep change.

Changes or developments will be made possible by the modernization of the way of thinking of members of indigenous peoples and law enforcers. In principle, customary law is people's law. As the people's law that regulates life that is constantly changing and developing, the maker is the people themselves. Therefore customary law undergoes continuous changes through decisions or settlements issued by the community as a result of consensus and deliberation through deliberation. Every development that occurs is always endeavored to have a place in the customary law system.

The effectiveness of traditional inheritance law in Berbah District, Sleman Regency: Berbah Subdistrict, Sleman Regency, is one of the government areas located on the outskirts of the Sleman Regency government, precisely on the border with Klaten Regency. In general, the people are effective in recognizing parental forms of kinship. Namely the kinship system, where there is a balance of position between husband and wife or withdrawing from the maternal line.

Based on the data above, after discussion with competent parties, it turns out that in accordance with Hilman Hadikusuma ${ }^{8}$ opinion, that the parental kinship system, the blood relationship system is no different from the father's and mother's descent system and generally applies the custom of free marriage, where after the husband's marriage wife live independently.Then if you do not have children, the adoption of a male or female child may apply. So it can be understood that the parental/bilateral kinship system is a kinship system that draws lineages from two sides, both from the father's side and from the mother's side.

Further data obtained that in general in the people of Berbah District, there is an equal inheritance position between boys and girls, or in other words there is an equal right to the acquisition of inheritance from the heir, namely his parents. This is in accordance with the provisions that apply to the parental or bilateral system which draws lineage from two sides, both from the father's side and from the mother's side, the position of boys and girls in the law of inheritance is equal and 
equal, meaning that both boys. as well as daughters are heirs of their parents' inheritance ${ }^{2}$.

However, data is obtained, there are a small number of families who when dividing the inheritance, only boys get more inheritance assets with daughters, namely 2 to 1 in accordance with the provisions of Islamic Inheritance Law.

As understood, the inheritance customary law is the rules of customary law that govern how the inheritance or inheritance is passed on or shared from heirs to experts from generation to generation ${ }^{9}$.

Of course, there is an atmosphere of mysticism for each family in dividing the inheritance for their children or generations of descendants. Because customary law is a dynamic law, it can adapt to certain situations and conditions. So when the provisions of the customary inheritance law are not implemented by certain families, it does not mean that the community must make a problem. The most important thing is that the principles of sharing his customary heritage are fulfilled.

Factors of traditional inheritance law in Berbah sub-district, Sleman regency: In connection with the factors that cause Adat Waris Law to be effective in Berbah District, Sleman Regency, data is obtained that the people of Berbah Subdistrict have a high level of compliance in carrying out the distribution of inheritance according to their customary provisions, because so far there have been relatively no internal conflicts between the heirs in a family who carry out the distribution of inheritance from their parents. The existence of a magical religious basis of thought in the people of Berbah District, Sleman Regency, on the implementation of inheritance distribution pays more attention to the heirs, parents and ancestors who have died calm in their graves. Mean while, the process of distributing inheritance by using the principle of cumunal or togetherness, the principle of deliberation and the principle of benefit in accordance with the provisions of customary law. So the most important thing is to be able to receive the results of the deliberations while still upholding the principle of harmony.

Furthermore, the results of the above research, conducted discussions with competent parties, so it can be understood that the customary inheritance law in the Berbah District generally shows a distinctive feature of the traditional Indonesian mindset, which is based on the principles that arise from a mind that is imbued with communal traits (togetherness), kinship, unity and oneness.

Some of the legal principles underlying the inheritance customary law are that according to the customary law system, inheritance property is not an entity that can be valued in money but is a unit that is not divided or can be divided according to types and kinds and based on the interests of the inheritors ${ }^{10}$. According to the customary law system, inheritance is based on equal rights, meaning that the rights of each heir are required to be the same in the process of passing on and passing on assets, and are placed on the basis of harmony in the process of distribution. Customary inheritance law adheres to the principle of open inheritance, which can be carried out while the heir is still alive and after he dies. So, customary inheritance law does not recognize any time when experts demand the opening of an inheritance. Settlement of inheritance using divine law principles, self-control, deliberation and consensus, harmony and kinship, and mutual rights.

Inheritance customary law is a form of the legal system that applies to the Indonesian people, especially those who are subject to customary law. Customary inheritance law is based or based on the principles of the characteristics of the traditional Indonesian school of thought, which have distinctive features, namely communal, religious magic, concrete, and cash (cash). Hazairin said that customary inheritance law has its own characteristics, namely that which originates from the minds of traditional communities with the form of kinship whose descent systems are based on patrilineal, matrilineal, and parental/bilateral ${ }^{9}$. Based on this distinctive feature, customary inheritance law is different from Islamic and western inheritance law. These differences stem from the way of thinking and way of life, such as customary inheritance law based on collective-communal rationalism, while western inheritance law is based on individualism.

\section{Conclusion}

In general, people in the Berbah District of Sleman Regency recognize parental forms of kinship. Namely the kinship system, where there is a balance of position between husband and wife or withdrawing from the father and mother line. There is an equal inheritance between boys and girls, or there is an equal right to the acquisition of inheritance from the heir, namely his parents. 
The factors causing the inheritance customary law are still effective in Berbah District, Sleman Regency, namely: a). The people of Berbah District have a high level of compliance in carrying out the distribution of inheritance in accordance with their customary provisions, because so far there has never been an internal conflict between the heirs in a family that distributes inheritance from their parents. b). The existence of a magical religious basis of thought in the people of Berbah District, on the implementation of the distribution of inheritance, pays more attention to the heirs, parents and ancestors who have died calm in their grave. c). The process of distributing inheritance by more using the principle of cumunal or togetherness, the principle of deliberation and the principle of benefit in accordance with the provisions of customary law. So the most important thing is to be able to receive the results of the deliberations while still upholding the principle of harmony.

Suggestion: Village apparatus, especially in the Berbah sub-district, Sleman Regency, as well as related officials, so that they can better understand the substance of the distribution of inheritance carried out by their residents. So that there is certainty to provide legal protection for parties related to the distribution of inheritance.

Village apparatus in the Berbah Subdistrict, Sleman Regency, should be able to act as mediators in resolving disputes that may arise as a result of the distribution of inheritance carried out based on local customary law, in a fair manner.

Ethical Clearance: This research was ethically approved by Faculty of Law, Universitas Diponegoro, Semarang, Indonesia
Funding: This research receives funding from Faculty of Law, Universitas Diponegoro, Semarang, Indonesia.

Conflict of Interests: There are no conflict of interests

\section{References}

1. Sismarwoto E. Islamic ethical value of customary basis of marriage proposal application in Indonesia. Indian Journal of Forensic Medicine and Toxicology. 2020;14(3): 1843-1846.

2. Suparman E.Intisari Hukum Waris Indonesia. Armico; 1985

3. Mulyadi L. Interpretation of judges in representing the dynamics of religion of indigenous legal inheritance of Bali. Jurnal Hukum dan Peradilan. 2019 Jul 31;8(2):214-27.

4. Soepomo, R. Bab-bab Hukum Adat. Jakarta: Pradnya Paramita;1981

5. Prodjodikoro, W. Hukum warisan di Indonesia. Sumur Bandung; 1966.

6. Sendratari, LP. Perempuan Bali: Wajah Sejuta Warna (Kajian tentangReproduksi dan Resistensiterhadap Patriarki). Media Komunikasi Singaraja; 2002.

7. Sudiyat I. Hukum adat: sketsa asas. Liberty Yogyakarta; 1981.

8. Hadikusuma H.. Pokok-pokok pengertian hukum adat. Alumni; 1980.

9. Hilman H. Pengantar Ilmu Hukum Adat Indonesia. Mandar Maju, Bandung; 1992

10. Samosir D. Hukum adat: eksistensi dalam dinamika perkembangan hukum di Indonesia. Nuansa Aulia; 2013. 